\title{
INFRASTRUKTURALNE MOŻLIWOŚCI DYWERSYFIKACJI DOSTAW GAZU ZIEMNEGO DO POLSKI W PERSPEKTYWIE 2020 ROKU
}

\begin{abstract}
Dywersyfikacja kierunków dostaw gazu ziemnego do Polski jest istotnym czynnikiem wpływającym na poziom bezpieczeństwa energetycznego kraju. Surowiec ten wykorzystywany jest w Polsce przede wszystkim przez przemysł chemiczny oraz petrochemiczny, a jego znaczenie w skali światowej będzie w nadchodzącym czasie rosło ze względu na zaostrzające się kryteria polityki klimatycznej UE. Krajowe wydobycie gazu ziemnego zaspokaja około $30 \%$ zapotrzebowania, a więc pozostała ilość importowana głównie z kierunku wschodniego od rosyjskiego Gazpromu. Struktura dotychczasowych kontraktów długoterminowych uzależniła Polskę od dostaw gazu ziemnego z Rosji. Szansą na zmianę tej sytuacji jest rozbudowa infrastruktury energetycznej w postaci terminalu LNG w Świnoujściu oraz połączeń międzysystemowych gazu ziemnego (tzw. interkonektorów) z państwami sąsiadującymi. Implementacja przepisów unijnych związanych $\mathrm{z}$ budową wspólnego rynku wraz z rozbudową infrastruktury gazowej, sprawia, że Polska zwiększy możliwości zróżnicowania kierunków dostaw tego surowca. Jeżeli zrealizowane zostaną najważniejsze projekty infrastruktury energetycznej planowane przez spółkę Gaz-System to Polska stanie się istotnym elementem zintegrowanego rynku energii oraz zmieni kierunki dostaw błękitnego paliwa. Należy przypuszczać, że wraz z otwarciem konkurencji na polskim rynku energii zwiększy się aktywność zagranicznych przedsiębiorstw energetycznych, które będą próbowały rywalizować z polskimi podmiotami o odbiorców końcowych. Szczególną aktywnością powinny wykazywać się przedsiębiorstwa rosyjskie oraz niemieckie. Budowa wspólnego rynku energii UE może doprowadzić do sytuacji, że gaz ziemny stanie się powszechnie dostępnym surowcem, a jego cena będzie coraz bardziej konkurencyjna.
\end{abstract}

Słowa kluczowe: Dywersyfikacja, gaz ziemny, infrastruktura energetyczna, terminal LNG, bezpieczeństwo energetyczne

\section{WSTĘP}

Bezpieczeństwo energetyczne państwa jest rodzajem bezpieczeństwa ekonomicznego, które zależy od wielu czynników. Niezwykle istotnym elementem wpływającym na jego poziom jest zasobność surowców energetycznych, które wykorzystywane są jako rodzaj paliwa do produkcji energii finalnej, a więc energii elektrycznej oraz cieplnej. W dobie współczesnych wyzwań energetyczno-klimatycznych są preferowane czyste paliwa, które podczas procesu spalania wytwarzają jak najmniejsze ilości dwutlenku węgla oraz innych gazów cieplarnianych. Bez wątpienia takim surowcem energetycznym jest gaz ziemny. Polska, podobnie jak większości państw Unii Europejskiej (UE), nie ma wystarczających

${ }^{1}$ Dr Mariusz Ruszel, Katedra Ekonomii, Wydziału Zarządzania, Politechnika Rzeszowska, al. Powstańców Warszawy 8, 35-959 Rzeszów, tel. (017) 865 1403, e-mail: mruszel@prz.edu.pl 
ilości własnego gazu, który zapewniłby państwu samowystarczalność energetyczną. Oznacza to konieczność importowania tego surowca $z$ innych państw, a dominującym dotychczas kierunkiem dostaw był kierunek wschodni. Niemniej jednak uzależnienie od jednego dostawcy negatywnie wpływa na bezpieczeństwo energetyczne państwa oraz na cenę importowanego gazu ziemnego, szczególnie w sytuacji gdy państwo eksportujące wykorzystuje dostawy surowców energetycznych jako instrument realizacji interesów politycznych

i strategicznych. Takim państwem jest Federacja Rosyjska, która wykorzystuje dostawy gazu ziemnego do Europy Środkowo-Wschodniej jako instrument odbudowywania wpływów politycznych - zgodnie $\mathrm{z}$ założeniami doktryny Falina ${ }^{2}$. W polityce energetyczne Rosji widoczne są założenia teorii realizmu ${ }^{3}$. Należy podkreślić, że brak możliwości dywersyfikacji dostaw surowców może osłabiać pozycję negocjacyjną w zakresie ustaleń warunków kontraktów gazowych.

Dywersyfikacja kierunków dostaw gazu ziemnego jest istotnym czynnikiem wpływającym na bezpieczeństwo energetyczne państwa. Znaczenie tego aspektu określa poziom rozbudowy infrastruktury energetycznej, w tym przepustowość gazociągów przesyłowych oraz połączeń międzysystemowych (tzw. interkonektorów gazowych) umożliwiających import surowca. Szacuje się, że dywersyfikacja kierunków dostaw gazu ziemnego jest czynnikiem mającym około 30\% wpływu na ogólny poziom bezpieczeństwa energetycznego Polski ${ }^{4}$. Szczególnie istotne są: kierunek dostaw surowca, państwo pochodzenia gazu ziemnego oraz struktura terminowa koszyka kontraktów importowych. Dywersyfikacja kierunków dostaw gazu ziemnego umożliwia import surowca od różnych dostawców, a więc zwiększa stabilność i ciągłość dostaw tego paliwa w sytuacji kryzysowej. Oczywiście realizacja skutecznej polityki dywersyfikacji dostaw wymaga odpowiednich inwestycji w infrastrukturę energetyczną, która umożliwi sprowadzenie surowca $\mathrm{z}$ różnych źródeł. Powszechnie przyjętym rozwiązaniem było dotychczas budowanie rurociągów, które zapewniały stabilność dostaw, lecz wskutek ogromnych kosztów oraz ryzyka inwestycyjnego musiały być poparte odpowiednimi kontraktami długoterminowymi, które zapewnią odpowiednią stopę zwrotu dla inwestorów. Szacuje się, że w perspektywie 2020 r. coraz większe znaczenie będą miały połączenia międzysystemowe, które zintegrują poszczególne regionalne grupy gazowe, utworzone uprzednio z narodowych rynków gazowych, w jeden wspólny rynek energii w

\footnotetext{
${ }^{2}$ Doktryna Falina została sformułowana w kwietniu 1991 r. i została uznana za strategię działania politycznego Związku Radzieckiego (a po jego rozpadzie Federacji Rosyjskiej) wobec państw Europy Środkowo-Wschodniej. Rosja chciała utrzymać wpływy w regionie oraz zapobiec rozwojowi współpracy militarnej byłych państw satelickich z zachodnioeuropejskimi organizacjami poprzez uzależnienie tych państw od dostaw surowców energetycznych, czyli ropy naftowej i gazy ziemnego. Zob. J. Strzelczyk, Jaka była geneza doktryny Falina i jaki byt jej sens?, Europa Bezpieczeństwo Energia, http://ebe.org.pl/analizy/joanna-strzelczyk-odpowiada-na-krotkiepytania.html (dostęp: 18.01.2013).

${ }^{3}$ Zob. T. Łoś - Nowak, Stosunki międzynarodowe. Teorie - systemy - uczestnicy, Wydawnictwo Uniwersytetu Wrocławskiego, Wrocław 2000, s. 44-45. Por. H. Morgenthau, Politics among Nations. The Struggle for Power and Peace, New York 1967, s. 225. Por. J. Czaputowicz, Teorie stosunków międzynarodowych. Krytyka i systematyzacja, Wydawnictwo Naukowe PWN, Warszawa 2008, s. 176-212.

${ }^{4}$ Zob. Bezpieczeństwo energetyczne Polski 2010. Raport otwarcia, Instytut Kościuszki, Kraków 2010, s. 12-14.
} 
UE, który będzie się cechował wolną konkurencją. Celem niniejszego artykułu jest określenie kierunków dywersyfikacji dostaw gazu ziemnego do Polski w perspektywie 2020 r. z uwzględnieniem prognozowanych, technicznych możliwości infrastruktury energetycznej oraz zapotrzebowania kraju na ten surowiec.

\section{ZNACZENIE GAZU ZIEMNEGO}

Unia Europejska przyjęła kierunek polityki energetyczno-klimatycznej, który wskazuje, w nadchodzących latach promowane będzie spalanie surowców czystych oraz niskoemisyjnych, do których zalicza się gaz ziemny. Prognozy Międzynarodowej Agencji Energii (IEA, International Energy Agency) podkreślają, że w perspektywie $2035 \mathrm{r}$. światowy popyt na ten surowiec zwiększy się do 5,1 biliona $\mathrm{m}^{3}$ gazu ziemnego rocznie w porównaniu z 3,3 biliona $\mathrm{m}^{3}$ rocznie w 2011 r. $^{5}$. Według Jean-Claude Depaila, prezydenta Gas Infrastructure Europe gaz ziemny występuje w dużych ilościach, jest dostępny cenowo, ma akceptację społeczną, stanowi szybką drogę do redukcji dwutlenku węgla oraz jest bezpiecznym i pewnym paliwem zapewniającym bezpieczeństwo energetyczne Europy ${ }^{6}$. Oznacza to, że nadchodzące dekada może się okazać „złotym okresem” dla gazu ziemnego. Tym bardziej że w Europie powstają kolejne akty prawne promujące paliwa niskoemisyjne, a instytucje udzielające kredytów na projekty energetyczne zaostrzają kryteria środowiskowe, co jednoznacznie obniża konkurencyjność projektów węglowych ${ }^{7}$.

W Polsce gaz ziemny wykorzystywany jest przede wszystkim przez przemysł, a także przez gospodarstwa domowe, które konsumują średnio około 30\% łącznej ilości sprzedawanego w Polsce surowca. Pozostała ilość tego paliwa trafia do zakładów chemicznych, petrochemicznych, przedsiębiorstw sektora paliwowego, rafinerii oraz do operatora systemu przesyłowego i operatorów systemu dystrybucyjnego na potrzeby własne oraz bilansowania systemu (w tym pokrycie strat przesyłowych). Oznacza to, że potrzeby gospodarstw domowych mogłyby być w pełni zaspokojone przez wydobycie $\mathrm{z}$ krajowych złóż gazu ziemnego. Obecnie paliwo to w niewielkim stopniu odpowiada za zapewnianie bezpieczeństwa elektroenergetycznego państwa, gdyż produkcja energii elektrycznej oparta jest na spalaniu węgla kamiennego i brunatnego. Szacuje się, że z węgla wytwarza się około $84-87 \%$ energii elektrycznej, z gazu ziemnego zaś zaledwie około $3 \%^{8}$. W perspektywie 2020 r. znaczenie ,czarnego paliwa” będzie znaczące w kontekście bezpieczeństwa elektroenergetycznego kraju, lecz znaczenie „błękitnego

\footnotetext{
${ }^{5}$ Are we entering a golden age of gas? Special Report, World Energy Outlook 2011, International Energy Agency, France 2011, s. 7-8.

${ }^{6}$ J.-C. Depail, Gas proces in Europe will drop, [w:] Future of Gas - A strategic view into the future, report summarizing $10^{\text {th }}$ international conference of Gas Infrastructure Europe, Kraków 24-25 May 2012, s. 4.

${ }^{7}$ Europejski Bank Inwestycyjny zamierza wspierać inwestycje w sektorze energii, które nie przekroczą progu emisyjnego na poziomie $550 \mathrm{~g} \mathrm{CO}_{2} / \mathrm{kWh}$, najniższym progiem emisyjnym dla projektów węglowych zaś jest $700 \mathrm{~g} \mathrm{CO}_{2} / \mathrm{kWh}$. M. Sankowski, Europejski Bank Inwestycyjny nie chce elektrowni węglowych. Rząd w potrzasku?, http://www.defence24.pl/europejski-bankinwestycyjny-nie-chce-elektrowni-weglowych-rzad-potrzasku/ (dostęp: 3.08.2013).

${ }^{8}$ W 2011 r. wyprodukowano w Polsce 163 GWh energii elektrycznej, z czego na gazie ziemnym wyprodukowano 4,3 GWh (niecałe 3\%). M. Kaliski, A. Szurlej, Z. Grudziński, Wegiel i gaz ziemny w produkcji energii elektrycznej Polski i UE, „Polityka energetyczna” 15/4 (2012), s. 207.
} 
paliwa" zapewne będzie stopniowo rosło. Przyczyną tych stopniowych zmian będą zaostrzające się unijne normy ochrony środowiska oraz nowe instrumenty fiskalne polityki klimatycznej UE, które będą zachęcać przede wszystkim do inwestycji w czyste źródła energii, a także będą obniżać konkurencyjność węgla kamiennego i brunatnego w energetyce na rzecz gazu ziemnego, odnawialnych źródeł energii, energetyki jądrowej.

\section{ZUŻYCIE GAZU ZIEMNEGO W POLSCE}

W 2012 r. polska gospodarka zużyła $15,8 \mathrm{mld}^{3}$ gazu ziemnego ${ }^{9}$, co stanowi pewien wzrost w porównaniu z wcześniejszymi latami, kiedy wykorzystanie to oscylowało wokół wartości 14,4-14,5 mld $\mathrm{m}^{3}$ surowca. Największym dostawcą gazu ziemnego do odbiorców końcowych jest Polskie Górnictwo Naftowe i Gazownictwo (PGNiG), które sprzedało w 2012 r. na krajowym rynku 14,9 $\mathrm{mld}^{3}$. Zapotrzebowanie na gaz ziemny pokrywane jest przede wszystkim z importu, gdyż krajowe wydobycie zaspokaja około $30 \%$ zapotrzebowania $\left(4,4 \mathrm{mld}^{3}\right.$ gazu ziemnego wydobyto w $2012 \mathrm{r}$. - w przeliczeniu na surowiec wysokometanowy). Można przypuszczać, że w perspektywie 2020 r. roczne krajowe wydobycie konwencjonalnego gazu ziemnego może osiągnąć poziom 4-6 mld $\mathrm{m}^{3}$ rocznie. Czynnikiem mogącym wpływać na poziom własnego wydobycia surowca jest zwiększenie efektywności wychwytywania gazu ziemnego przy eksploatacji ropy naftowej oraz węgla, rozpoczęcie wydobycia ze złóż zagranicznych należących do PGNiG, a także wydobycie gazu ze skał łupkowych.

W perspektywie 2020 r. trudno jednoznacznie określić poziom zapotrzebowania polskiej gospodarki na gaz ziemny. W ostatnich latach wzrastało ono na poziomie około 2\% w skali roku. Dynamiczniejszy wzrost będzie możliwy w wypadku podjęcia decyzji inwestycyjnych dotyczących budowy nowych mocy wykorzystujących gaz ziemny do produkcji energii elektrycznej oraz cieplnej. Wielu inwestorów zwleka z ostatecznymi decyzjami, czekając na regulacje prawne dotyczące kogeneracji gazowej oraz odnawialnych źródeł energii ${ }^{10}$. Najprawdopodobniej wiele rozstrzygnie się dopiero w 2014 r. Niemniej jednak jeżeli w perspektywie 2018 r. powstałyby planowane nowe moce, to wzrost zapotrzebowania na surowiec zwiększyłby się tylko z tych inwestycji na poziomie około $7 \mathrm{mld}^{3}$. Scenariusz ten wydaje się jednak mało realny, gdyż wiele inwestycji $\mathrm{w}$ sektorze energii nie jest obecnie realizowanych $\mathrm{w}$ terminie. Ponadto $\mathrm{w}$ sytuacji braku stabilności regulacji prawnych proces decyzyjny związany z budową nowych mocy będzie się przeciągał w czasie. Należy pamiętać o systematycznie spadających cenach węgla, do czego przyczyniła się rewolucja gazu z łupków w Stanach Zjednoczonych, gdyż na rynkach światowych są coraz większe nadwyżki niektórych surowców energetycznych. Stosownie do obecnie obowiązującej, chociaż coraz mniej aktualnej strategii „Polityka energetyczna Polski do 2030 roku” zapotrzebowanie na gaz ziemny w $2020 \mathrm{r}$. wyniesie $17,1 \mathrm{mld} \mathrm{m}^{3}$. Z kolei według byłego wiceprezesa PGNiG

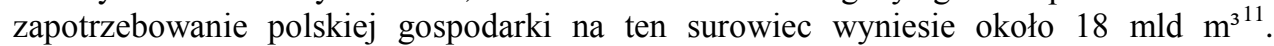

\footnotetext{
9 Wydobycie $i$ zużycie gazu w Polsce $w$ liczbach, http://www.mg.gov.pl/node/18029 (dostęp: 21.04.2013).

${ }_{10}$ D. Ciepiela, Elektrociepłownie gazowe na razie nie powstana?, http://www.wnp.pl/drukuj/172767_1.html (dostęp: 5.08.2013).

11 Zużycie gazu $w$ Polsce $w 2020$ r. ma być nie mniejsze niz 18 mld $m$ sześś. http://gazownictwo.wnp.pl/zuzycie-gazu-w-polsce-w-2020-r-ma-byc-nie-mniejsze-niz-18-mld-mszesc,140868_1_0_0.html (dostep: 2.08.2013).
} 
Według spółki Gaz-System zapotrzebowanie na gaz ziemny w 2020 r. wyniesie $18,5 \mathrm{mld}$ $\mathrm{m}^{3}$ rocznie ${ }^{12}$. Według autora najbardziej realna jest prognoza wskazująca zapotrzebowanie na poziomie $18-18,5 \mathrm{mld} \mathrm{m}^{3}$ gazu ziemnego rocznie.

Biorąc pod uwagę, że w nadchodzących latach będzie wzrastało zapotrzebowanie gospodarki na gaz ziemny, a także zwiększać się będzie szczytowe zapotrzebowanie na ten surowiec, to zasadne jest zwiększenie zdolności magazynowych kraju. Obecnie podziemne magazyny gazu (PMG) mogą pomieścić $1,822 \mathrm{mld} \mathrm{m}^{3}$, z czego $883,7 \mathrm{mln} \mathrm{m}^{3}$ surowca stanowiły w 2012 r. zapasy obowiązkowe. Istotne znaczenie będzie miała rozbudowa $\mathrm{PMG}^{13}$ oraz zwiększenie przepustowości przyłączy do systemu przesyłowego w taki sposób, aby zwiększyć ilość gazu ziemnego oddawanego z magazynów do tego systemu. PMG spełniają bardzo ważną funkcję $\mathrm{z}$ punktu widzenia bezpieczeństwa energetycznego Polski, gdyż pozwalają wyrównywać wahania sezonowe gazu ziemnego i zazwyczaj zapełniane są w okresie letnim, a opróżniane w okresie zimowym. Obecnie Polska ma osiem PMG (Wierzchowice, Husów, Strachocina, Swarzów, Brzeźnica, Mogilno, Daszewo, Bonikowo), a planowy jest również kolejny - Kosakowo. Wszystkie obiekty tej infrastruktury energetycznej należą do spółki PGNiG. Szacuje się, że w perspektywie $2020 \mathrm{r}$. zdolności podziemnych magazynów gazu powinny wynosić około 3 mld $\mathrm{m}^{3}$ gazu ziemnego. Zapotrzebowanie na gaz ziemny możne również wzrosnąć $\mathrm{w}$ perspektywie $2020 \mathrm{r}$. jeżeli rozwijany będzie „rynek mocy” w UE ${ }^{14}$.

\section{KIERUNKI DOSTAW GAZU ZIEMNEGO DO POLSKI}

Stosownie do Rozporządzenia Rady Ministrów z dnia 24 października 2000 r. w sprawie minimalnego poziomu dywersyfikacji dostaw gazu z zagranicy maksymalny udział gazu importowanego $\mathrm{z}$ jednego kraju pochodzenia w stosunku do całkowitej wielkości nie powinien być większy niż 49\% w latach 2019-2020 $0^{15}$. Oznacza to, że polityka energetyczna Polski powinna dążyć do zróżnicowania źródeł dostaw gazu ziemnego. Polska obecnie ma techniczne możliwości importowania gazu ziemnego z kierunku wschodniego, zachodniego oraz południowego. W perspektywie 2020 r. Polska będzie mogła dodatkowo sprowadzać surowiec za pośrednictwem kierunku północnego. Gaz ziemny importowany do kraju w 2012 r. pochodził przede wszystkim z krajów Azji Środkowej, Azerbejdżanu oraz Federacji Rosyjskiej. Z kierunku wschodniego Polska kupiła 9 mld $\mathrm{m}^{3}$ surowca $\mathrm{w}$ ramach kontraktu długoterminowego (tzw. kontrakt jamalski)

\footnotetext{
${ }^{12}$ Są to szacunkowe prognozy według wariantu umiarkowanego wzrostu dotyczące zapotrzebowania na usługę przesyłową. Prognoza została skonstruowana na podstawie umów przesyłowych z uwzględnieniem podpisanych umów na przyłączenie nowych bloków parowogazowych w elektrociepłowni Stalowa Wola i Włocławku. Plan rozwoju w zakresie zaspokojenia obecnego i przyszlego zapotrzebowania na paliwa gazowe na lata 2014-2023, Gaz-System, Warszawa, 1 lipca 2013 r., s. 11-13, http://www.gaz-

system.pl/fileadmin/pliki/do_pobrania/pl/plan_rozwoju/Wyciag_z_Planu_Rozwoju_zapotrzebowani a na_paliwa_gazowe 2014-2023.pdf (dostepp: 5.08.2013).

${ }^{13}$ Pojawiają się również inne poglądy w tym również takie, że Polska powinna zintensyfikować współpracę z Litwą, Łotwą i Estonią również w zakresie wykorzystywania podziemnych magazynów gazu na Łotwie.

${ }^{14}$ D. Ciepiela, Wkrótce w UE będzie jednolity rynek mocy?, http://energetyka.wnp.pl/wkrotce-w-uebedzie-jednolity-rynek-mocy,203687_1_0_0.html (dostęp: 16.08.2013).

${ }^{15}$ Rozporzadzenie Rady Ministrów z dnia 24 października 2000 r. w sprawie minimalnego poziomu dywersyfikacji dostaw gazu z zagranicy, Dz. U. Nr 95, Poz. 1042.
} 
podpisanego pomiędzy PGNiG a Gazpromem. Z kierunku zachodniego - od Niemiec Polska kupiła 1,7 mld $\mathrm{m}^{3}$ gazu ziemnego, z kierunku południowego zaś - z Czech zakupiono około $0,5 \mathrm{mld} \mathrm{m}^{3}$ surowca ${ }^{16}$. Głównym importerem surowca jest polska spółka PGNiG, która zakupiła łącznie w 2012 r. około 10,9 mld $\mathrm{m}^{3}$ gazu ziemnego.

Największe ilości tego surowca zostały dostarczone przez rosyjski koncern Gazprom i w perspektywie 2020 r. sytuacja ta najprawdopodobniej się nie zmieni. Wynika to z tzw. kontraktu jamalskiego, który został zawarty 25 września 1996 r. pomiędzy PGNiG a Gazpromem ${ }^{17}$. Kolejne aneksy do tego kontraktu, w tym protokół dodatkowy z 2003 r., podobnie jak sam kontrakt, zawierały zapisy, które okazały się niekorzystne dla polskiej gospodarki ${ }^{18}$. Ostatnie porozumienie między stronami z 29 października $2010 \mathrm{r}$. zobowiązuje do odbioru PGNiG około $10 \mathrm{mld} \mathrm{m}^{3}$ gazu ziemnego rocznie do $2022 \mathrm{r}$. ${ }^{19}$. Choć klauzula take or pay obejmuje $85 \%$ zakontraktowanego surowca, a więc polska spółka nie musi odbierać $15 \%$ bez żadnych konsekwencji finansowych. Oznacza to, że w 2020 r. PGNiG odbierze około $8,5 \mathrm{mld}^{3}$ gazu ziemnego od rosyjskiego Gazpromu. Surowiec dostarczany jest do polskiego systemu gazowego w punktach wejścia związanych z importem w miejscowościach: Drozdowicze (granica polsko-ukraińska, przepustowość 5,7 $\mathrm{mld}^{3}$ rocznie), Wysokoje (granica polsko-białoruska, przepustowość $5,5 \mathrm{mld} \mathrm{m}^{3}$ rocznie) oraz na gazociągu jamalskim (gazociąg Jamał-Europa) w miejscowościach: Włocławek (przepustowość $3,1 \mathrm{mld} \mathrm{m}^{3}$ rocznie) i Lwówek (przepustowość $2,4 \mathrm{mld}^{3}$ rocznie).

Polska sprowadzała w ostatnich latach gaz ziemny z Ukrainy na podstawie kontraktów zawieranych pomiędzy PGNiG a Naftohazem oraz RosUkrEnergo. Sytuacja się zmieniła i obecnie to Polska stanowi kraj tranzytowy od 1 listopada 2012 r. do importu gazu ziemnego

z Niemiec na Ukrainę na podstawie kontraktu zawartego pomiędzy RWE a Naftohazem. Przez Polskę przesyłano początkowo $2 \mathrm{mln}^{3}$ na dobę, a od 1 kwietnia 2013 r. ilość została zwiększona do $5 \mathrm{mln} \mathrm{m}^{3}$ na dobę. Jeżeli Ukraina zdecyduje się w perspektywie 2020 r. na kurs prozachodni i utrzyma ambicje dywersyfikacji dostaw gazu ziemnego wraz z zachowaniem kontroli nad gazociągami, to Polska może być istotnym partnerem ułatwiającym zaopatrywanie Ukrainy $\mathrm{w}$ ten surowiec. W wypadku utraty kontroli nad ukraińską infrastrukturą energetyczną na rzecz Rosji kierunki dostaw gazu ziemnego mogą się znacząco zmienić. Niemniej jednak w analizowanej perspektywie czasu Ukraina raczej nie będzie importowała gazu ziemnego do Polski z wyjątkiem ewentualnego

16 D. Malinowski, $W 2012$ r. Polska zużyła rekordowe 15,8 mld $m^{3}$ gazu, http://gazownictwo.wnp.pl/w-2012-r-polska-zuzyla-rekordowe-15-8-mld-m3gazu,194594_1_0_0.html (dostęp: 5.08.2013).

${ }^{17}$ Należy zauważyć, że na szczeblu rządowym pomiędzy obydwoma państwami podpisano w 1993 r. Porozumienie między Rzadem Rzeczypospolitej Polskiej a Rzadem Federacji Rosyjskiej o budowie systemu gazociagów dla tranzytu rosyjskiego gazu przez terytorium Rzeczypospolitej Polskiej $i$ dostawach rosyjskiego gazu do Rzeczypospolitej Polskiej z 25 sierpnia 1993 r. Zob. T. Kaźmierczak, Uzależnienie Polski od importu gazu ziemnego z Rosji, [w:] T. Kaźmierczak, Bezpieczeństwo energetyczne - implikacje uzależnienia Polski od importu gazu ziemnego (zarys problemu), Promotor, Warszawa 2008.

${ }^{18}$ A. Zawisza, Gaz dla Polski. Zarys historii sektora gazu ziemnego w ostatnich dwóch dekadach w Polsce, Instytut Sobieskiego, Warszawa 2011, s. 37.

19 Polsko-rosyjskie porozumienie ws. dostaw gazu podpisane, http://www.mg.gov.pl/node/11838 (dostęp: 1.08.2013). 
sprowadzania surowca ze złóż Sachalinskoje, do których w części prawa rości sobie PGNiG za pośrednictwem spółki Dewon (polski monopolista ma 36\% udziałów w tej firmie). Należy pamiętać, że pomiędzy Polską a Ukrainą funkcjonuje połączenie międzysystemowe w Drozdowiczach, które ma przepustowość $5,7 \mathrm{mld}^{3}$ rocznie i wykorzystywane jest do wypełniania zobowiązań rosyjskiego Gazpromu względem PGNiG w ramach kontraktu jamalskiego.

Wschodnim sąsiadem Polski jest również Białoruś. Na granicy łączącej oba państwa znajduje się połączenie międzysystemowe gazu ziemnego w miejscowości Tietierowka, które ma przepustowość na poziomie 27 tys. $\mathrm{m}^{3} /$ godzinę i może ona zostać zwiększona w 2016 r. do 42,8 tys. $\mathrm{m}^{3} /$ godzinę ${ }^{20}$. Obecnie połączenie umożliwia import surowca na poziomie $0,2 \mathrm{mld}^{3}$ rocznie. Na granicy istnieje również połączenie Wysokoje, które ma przepustowość $5,5 \mathrm{mld}^{3}$ gazu ziemnego rocznie i jest punktem zdawczo-odbiorczym dla kontraktu jamalskiego pomiędzy PGNiG a Gazpromem. W perspektywie 2020 r. nie należy się spodziewać rozbudowy przepustowości połączeń międzysystemowych pomiędzy państwami, punkt w Wysokoje zaś wykorzystywany będzie nadal na potrzeby kontraktu jamalskiego.

Ostatnim sąsiadem Polski od wschodniej strony jest Litwa, z którą obecnie państwo nie ma interkonektora gazowego. Niemniej jednak planowane jest połączenie, które mogłoby mieć przepustowość około 2,4-4,1 mld $\mathrm{m}^{3}$ surowca rocznie. Połączenie miałoby być dwukierunkowe, a więc miałoby na celu zwiększenie elastyczności dostaw gazu ziemnego do państw bałtyckich, integrując je tym samym ze wspólnym rynkiem energii UE. Stosownie do obecnych planów inwestycyjnych interkonektor mógłby powstać w okresie 2019-2023 r. ${ }^{21}$, a więc mało prawdopodobne jest, aby był funkcjonował już w $2020 \mathrm{r}$.

Z kierunku zachodniego Polska importuje gaz ziemny z Niemiec poprzez połączenie międzysystemowe w Lasowie oraz za pośrednictwem rewersu wirtualnego i fizycznego Mallnow na gazociągu jamalskim. Interkonektor w miejscowości Lasów od stycznia 2012 r. umożliwia import $1,5 \mathrm{mld} \mathrm{m}^{3}$ gazu ziemnego rocznie (wcześniej import ten mógł być realizowany na poziomie $0,9 \mathrm{mld} \mathrm{m}^{3}$ ). Należy przypuszczać, że w perspektywie $2020 \mathrm{r}$. pojawią się pomysły rozwoju przepustowości tego połączenia do $2 \mathrm{mld} \mathrm{m}^{3}$ rocznie. Większe możliwości sprzedaży Polsce gazu ziemnego przez Niemcy stwarzają rewers wirtualny i fizyczny na gazociągu jamalskim. Od listopada $2011 \mathrm{r}$. w ramach wirtualnego rewersu na zasadach przerywanych możliwy jest import $2,3 \mathrm{mld}^{3}$ gazu ziemnego rocznie do Polski. Gaz-System i GASCADE podpisali porozumienie 21 listopada $2012 \mathrm{r}$. dotyczące rozbudowy stacji pomiarowej Mallnow, dzięki czemu możliwe będą fizyczne

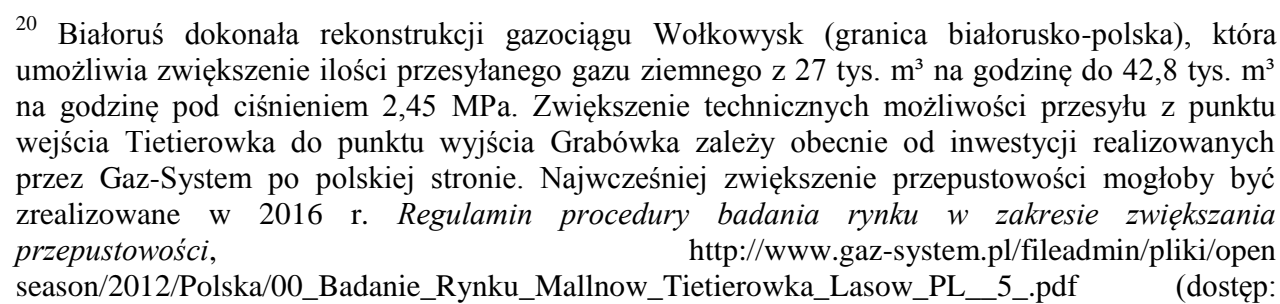

4.08.2013)

${ }^{21}$ Plan rozwoju w zakresie ..., s. 16. 
dostawy surowca ${ }^{22}$. Inwestycja realizowana jest zgodnie $\mathrm{z}$ wytycznymi zawartymi w Rozporzadzeniu Parlamentu Europejskiego i Rady (UE) nr 994/2010 z 20 października 2010 r. w sprawie środków zapewniających bezpieczeństwo dostaw gazu ziemnego ${ }^{23}$, które zakładają dwukierunkowe przepływu gazu ziemnego na połączeniach transgranicznych. Docelowo rewers fizyczny Mallnow na gazociągu jamalskim ma zapewniać ciągłą przepustowość na poziomie $5,5 \mathrm{mld}^{3}$ surowca rocznie. Szacuje się, że prace związane $\mathrm{z}$ budową rewersu fizycznego zostaną zakończone w 2014 r. Należy zauważyć, że na granicy polsko-niemieckiej znajduje się również lokalne połączenie w miejscowości Gubin. Ponadto istnieje jeszcze gazociąg należący do koncernu EWE, który przebiega pod Odrą w regionie Słubic ${ }^{24}$. Połączeniem tym dostarczany jest surowiec do kilkudziesięciu gmin lubuskich. Niemiecki koncern EWE zabiega o dostęp do polskiej sieci przesyłowej od kilku lat. Spółka współpracuje z rosyjskim koncernem Gazprom (obie firmy są współudziałowcami koncernu VNG) ${ }^{25}$. W perspektywie utworzenia jednolitego rynku energii UE, a więc w wyniku otworzenia się na konkurencję polskiego rynku, należy się spodziewać zwiększonej aktywności niemieckich spółek dążących do sprzedaży jak największej ilości gazu ziemnego zarówno poprzez kontrakty bezpośrednie z odbiorcami, jak i przez giełdę energii. Gaz ziemny sprowadzany do Polski z Niemiec będzie surowcem zakupiony wcześniej przez niemieckie spółki od rosyjskich kontrahentów, czyli Gazprom lub Novatek.

Na granicy południowej Polska ma interkonektor z Czechami w miejscowości Cieszyn oraz planuje budowę połączenia ze Słowacją. Połączenie polsko-czeskie zostało uruchomione we wrześniu $2011 \mathrm{r}$. i ma ono obecnie przepustowość $0,5 \mathrm{mld} \mathrm{m}^{3}$ gazu ziemnego rocznie. W maju 2011 r. PGNiG podpisało kontrakt ze szwajcarską spółką Vitol na dostawy około $0,5 \mathrm{mld} \mathrm{m}^{3}$ gazu ziemnego rocznie za pośrednictwem połączenia polsko-czeskiego. Zawarty kontrakt ma wartość około $550 \mathrm{mln}$ euro i będzie obowiązywał do 1 października 2014 r. Wykorzystywane połączenie polsko-czeskie może być rozbudowane do kilku mld $\mathrm{m}^{3}$ gazu ziemnego rocznie w obydwóch kierunkach. Teoretycznie połączenie mogłoby być rozbudowane w perspektywie $2018 \mathrm{r}$. W praktyce jego docelowa przepustowość zależeć będzie od zainteresowania podmiotów rynkowych tym połączeniem po obu stronach granicy. Obecnie poprzez polsko-czeski interkonektor dostarczany jest do kraju gaz ziemny pochodzenia rosyjskiego, gdyż szwajcarska spółka Vitol jest partnerem handlowym rosyjskiego Gazpromu, a w czeskich gazociągach przepływa rosyjski surowiec ${ }^{26}$. W perspektywie 2020 r. połączenie w Cieszynie będzie rewersowym interkonektorem o przepustowości $2-6 \mathrm{mld}^{3}$ gazu ziemnego rocznie. Należy zaznaczyć, że na granicy polsko-czeskiej znajdują się również lokalne połączenia

22 Fizyczny rewers na gazociagu jamalskim, http://www.gazsystem.pl/uploads/media/Fizyczny_rewers_na_gazociagu_jamalskim.pdf (dostęp: 9.08.2013).

${ }^{23}$ Rozporządzeniu Parlamentu Europejskiego i Rady (UE) nr 994/2010 z dnia 20 października 2010 r. w sprawie środków zapewniajacych bezpieczeństwo dostaw gazu ziemnego i uchylenia dyrektywy Rady 2004/67/WE, Dz. U. UE L 295/1.

${ }^{24}$ M. Duszczyk, Jest gazociag, jest gaz, ale nie ma chętnych, http://biznes.gazetaprawna.pl/artykuly/454984,jest_gazociag_jest_gaz_ale_nie_ma_chetnych.html (dostęp: 9.08.2013).

${ }^{25}$ Ibidem.

${ }^{26}$ PGNiG zamawia gaz z Czech od szwajcarskiej firmy Vitol, http://wyborcza.biz/biznes/1,101562,9595488,PGNiG_zamawia_gaz_z_Czech_od_szwajcarskiej_fi rmy_Vitol.html (dostęp: 7.08.2013). 
realizujące lokalny import gazu ziemnego w miejscowościach: Branice oraz Głuchołazy (jest to punkt rezerwowy).

Jednocześnie Polska i Słowacja planują budowę interkonektora w pobliżu miejscowości Komańcza, gdzie polski system przesyłowy gazu ziemnego miałby się połączyć z gazociągiem Braterstwo w stacji kompresorowej Vel'ke Kapusany. Połączenie to mogłoby mieć początkową przepustowość kilku miliardów $\mathrm{m}^{3}$ surowca. Szacuje się, że optymalnie połączenie zapewniałoby przepustowość $5,5 \mathrm{mld} \mathrm{m}^{3}$ do Polski (z możliwością rozbudowy do $9,5 \mathrm{mld}^{3}$ rocznie) oraz $4,7 \mathrm{mld}^{3}$ rocznie na Słowację. Stosownie do deklaracji politycznych obu państw oraz podpisanych listów intencyjnych na poziomie ministrów gospodarki w październiku 2012 r. budowa połączenia o długości $176 \mathrm{~km}$ rozpoczęłaby się w 2014 r. ${ }^{27}$. Budowa tego interkonektora przyczyni się do zróżnicowania kierunków dostaw gazu ziemnego do południowej części Polski, gdzie znajduje się infrastruktura magazynowa surowca, a także umożliwi potencjalny eksport gazu w wypadku pojawienia się nadwyżek na rynku krajowym bądź też w sytuacji kryzysowej na Słowacji stworzy możliwość sprowadzenia surowca za pośrednictwem terminalu LNG w Świnoujściu lub zakupu gazu z łupków - w wypadku przemysłowej eksploatacji tego niekonwencjonalnego surowca. Jednocześnie połączenia polsko-czeskie oraz polskosłowackie będą istotnymi elementami korytarza gazowego Północ-Południe, który przyczyni się do większej integracji rynku energii w UE.

Największą elastyczność w zakresie wyboru dostawcy gazu ziemnego do Polski zapewni kierunek północny dzięki wybudowaniu terminalu gazu skroplonego (LNG, Liquid Natural Gas) w Świnoujściu. Najprawdopodobniej gazoport zostanie oddany z pewnym opóźnieniem (planowany termin to połowa 2014 r.), lecz zwiększy on bezpieczeństwo energetyczne Polski oraz poprawi dywersyfikację kierunków dostaw surowca. Terminal LNG jest budowany przez spółkę Polskie LNG, która w pełni należy do spółki Gaz-System, w której 100\% udziału ma Skarb Państwa. Instalacja umożliwi początkowo na odbiór $5 \mathrm{mld}^{3}$ gazu ziemnego rocznie, $\mathrm{z}$ możliwością rozbudowy do 7,5 mld $\mathrm{m}^{3}$. Rozbudowa mocy regazyfikacji gazu ziemnego jednak raczej nie zostanie zrealizowana do 2020 r. Stosownie do planów spółki Gaz-System inwestycja ta planowana jest w perspektywie 2023 r. Należy przypuszczać, że funkcjonowanie gazoportu zwiększy pozycję negocjacyjną Polski wobec dotychczasowych dostawców oferujących dostawy gazu ziemnego w ramach kontraktów długoterminowych, a także przyczyni się do zwiększenia ilości surowca sprowadzanego do kraju w ramach kontraktów krótkoterminowych, a także transakcji typu spot. Spółka PGNiG podpisała z firmą Quatargas kontrakt na odbiór $1,5 \mathrm{mld}^{3}$ gazu ziemnego rocznie w okresie od 1 lipca 2014 r. do 31 grudnia 2034 r. Należy przypuszczać, że w perspektywie 2020 r. terminal LNG w Świnoujściu będzie częścią wspólnego rynku UE i stanie się jednocześnie istotnym elementem unijnego korytarza gazowego Północ-Południe, który ma połączyć polski gazoport z chorwackim terminalem LNG na wyspie Krk. Oznacza to, że terminal LNG w Świnoujściu będzie w 2020 r. jedną z kluczowych instalacji tego typu w regionie Morza Bałtyckiego.

\footnotetext{
27 Tusk: interkonektor gazowy ze Stowacją może powstać szybciej, http://biznes.pl/magazyny/energetyka/gazownictwo/tusk-interkonektor-gazowy-ze-slowacja-mozepowstac,5454972,magazyn-detal.html (dostęp: 9.08.2013).
} 


\section{WNIOSKI}

W perspektywie $2020 \mathrm{r}$. zrealizowane zostaną projekty infrastruktury gazowej, które przyczynią się do zwiększenia bezpieczeństwa energetycznego Polski na wspólnym rynku energii UE. Przede wszystkim rynek ten będzie się charakteryzował konkurencją oraz swobodą wyboru dostawcy surowca. Ważną rolę na zintegrowanym rynku energii będzie odgrywała spółka Gaz-System, która zgodnie z prawem energetycznym jest operatorem systemu przesyłowego ${ }^{28}$, a stosownie do decyzji Prezesa Urzędu Regulacji Energetyki mają koncesję na prowadzenie takiej działalności do 31 grudnia 2030 r. Spośród planowanych projektów dywersyfikacji kierunków dostaw gazu ziemnego w prognozowanym okresie powinny zostać zrealizowane kluczowe inwestycje zwiększające bezpieczeństwo energetyczne kraju. Wynika to zarówno z analizy strategii spółki GazSystem, jak i Rozporzadzenia Parlamentu Europejskiego i Rady (UE) Nr 347/2013 z dnia 17 kwietnia $2013 r$. w sprawie wytycznych dotyczacych transeuropejskiej infrastruktury energetycznej, uchylajace decyzje $n r$ 1364/2006/WE oraz zmieniające rozporzadzenia (WE) $n r$ 713/2009, (WE) $n r 714 / 2009 i$ (WE) $n r 715 / 2009^{29}$. Ten unijny akt prawny sprawi, że przyzpieszone zostaną prace nad tworzeniem grup regionalnych $\mathrm{w}$ obszarze energii, które będą dokonywały przeglądu projektów wspólnego zainteresowania. Tym samym stworzenie grup regionalnych stanie się etapem przejściowym, mającym na celu ostateczne zintegrowanie rynku energii. Zgodnie z założeniami zawartymi w niniejszym rozporządzeniu do „31 grudnia 2016 r. ENTSO energii elektrycznej i ENTSO gazu wspólnie przedstawią Komisji i Agencji spójny i wzajemnie powiązany model sieci i rynku energii elektrycznej i gazu, obejmujący zarówno infrastrukturę przesyłu energii elektrycznej, jak i gazu oraz obiekty magazynowania i LNG w priorytetowych korytarzach i obszarach infrastruktury energetycznej" ${ }^{30}$. Jednocześnie w załączniku nr I do rozporządzenia określone zostały priorytetowe korytarze i obszary infrastruktury energetycznej, wśród których znalazły się istotne między innymi dla Polski projekty, czyli elektroenergetyczne połączenia Północ-Południe w Europie Środkowo-Wschodniej, gazowe połączenia Północ-Południe w Europie Środowo-Wschodniej, południowy korytarz gazowy umożliwiający dostawy surowca z regionu Morza Kaspijskiego oraz rozbudowa połączeń gazowych i elektroenergetycznych łączących państwa bałtyckie $\mathrm{z}$ resztą unijnego rynku energii oraz połączenia dostawcze ropy naftowej do państw Europy Środkowo-Wschodniej. Zasadniczym celem UE jest stopniowa budowa zintegrowanego rynku energii, w którego ramach w perspektywie 2020 r. mają się pojawić pierwsze

\footnotetext{
${ }^{28}$ Poważnym problemem związanym $\mathrm{z}$ bezpieczeństwem dostaw gazu ziemnego do odbiorców końcowych jest struktura wiekowa gazociągów przesyłowych, z których ponad $60 \%$ ma więcej niż 25 lat, co stwarza szereg wyzwań inwestycyjnych przed spółką Gaz-System, która odpowiada za te gazociągi.

${ }^{29}$ Rozporzadzenie Parlamentu Europejskiego i Rady (UE) Nr 347/2013 z dnia 17 kwietnia 2013 r. w sprawie wytycznych dotyczacych transeuropejskiej infrastruktury energetycznej, uchylajace decyzje $n r$ 1364/2006/WE oraz zmieniajace rozporzadzenia (WE) $n r$ 713/2009, (WE) $n r$ 714/2009 i (WE) $n r$ 715/2009, Dz. U. UE L 115/39.

${ }^{30}$ Ibidem, art. 11 pkt 8.
} 
„autostrady elektroenergetyczne”, które pozwolą optymalnie zagospodarować nadwyżki energii elektrycznej.

Jeżeli w perspektywie 2023 r. zostaną zrealizowane planowane inwestycje przez spółkę Gaz-System (terminal LNG w Świnoujściu, budowa i rozbudowa interkonektorów), to zdolności importowe gazu ziemnego powinny wynosić - stosownie do scenariusza umiarkowanego wzrostu - około $34,2 \mathrm{mld}^{3}$ gazu ziemnego rocznie. Biorąc pod uwagę badaną perspektywę czasu na poziomie 2020 r., można określić poziom zdolności importowych infrastruktury gazowej na poziomie około $29,5 \mathrm{mld} \mathrm{m}^{3}$. Jeżeli weźmiemy pod uwagę, że polska gospodarka będzie potrzebowała wówczas około 18,5 mld $\mathrm{m}^{3}$ surowca, a krajowe wydobycie będzie na poziomie $4-5 \mathrm{mld}^{3}$, to oznacza to, że zakupimy około 13,5-14,5 $\mathrm{mld}^{3}$. Zapewne 8,5 $\mathrm{mld} \mathrm{m}^{3}$ lub mniej spółka PGNiG zakupi od rosyjskiego Gazpromu, 1,5 $\mathrm{mld}^{3}$ zaś od katarskiej spółki Quatargas. Pozostałe 3,54,5 $\mathrm{mld} \mathrm{m}^{3}$ gazu ziemnego dostarczone zostanie $\mathrm{z}$ innych kierunków. Należy się spodziewać, że największą aktywność w zakresie oferowania błękitnego paliwa na polski rynek będą wykazywać niemieckie koncerny energetyczne. Oznacza to, że 1,5 $\mathrm{mld} \mathrm{m}^{3}$ przypłynie do kraju poprzez interkonektor w Lasowie, około $2 \mathrm{mld}^{3}$ zaś $\mathrm{z}$ rewersu fizycznego na gazociągu jamalskim w punkcie Mallnow. Pozostała ilość surowca potrzebna polskiej gospodarce zostanie zakupiona z kierunku południowego na granicy polsko-czeskiej lub polsko-słowackiej.

Wskutek zaostrzających się regulacji prawnych na poziomie UE oraz coraz ostrzejszej konkurencji o odbiorcę gazu ziemnego w Europie, trudno oczekiwać, aby w 2020 r. był już wydobywany na szeroką skalę gaz z łupków w Polsce. Należy przypuszczać, że w analizowanej perspektywie czasu rozpocznie się wydobycie tego surowca, lecz będzie ono na umiarkowanym poziomie kilku $\mathrm{mld} \mathrm{m}^{3}$. Niemniej jednak przyspieszenie prac związanych z eksploatacją tego surowca jest szansą na zwiększenie samowystarczalności gazowej Polski po 2022 r., kiedy skończy się okres obowiązywania kontraktu jamalskiego. Jego ewentualne dalsze przedłużenie na warunkach rynkowych nie zawierałoby niedozwolonych klauzul kontraktowych, a także zapewniałoby pełną elastyczność odbioru surowca, stosownie do zapotrzebowania, po konkurencyjnych cenach. Należy zauważyć, że kluczowe będą lata 2018-2019, kiedy strona polska będzie prowadziła negocjacje z Rosjanami. Ważne jest, aby nie popełnić dotychczasowych błędów oraz zacząć patrzeć na gaz ziemny jako towar rynkowy, którego nadwyżki na rynku unijnym rozpoczną proces tworzenia korytarzy gazowych oraz autostrad elektroenergetycznych, dzięki którym poszczególne gospodarki będą musiały szukać nowych płaszczyzn przewag konkurencyjnych $\mathrm{w}$ sytuacji, gdy energia stanie się ogólnodostępnym dobrem, a gaz zastępowalnym surowcem dla przemysłu. Zredukowanie kosztów energii jest dzisiaj jednym z najważniejszych wyzwań dla Europy, gdyż nie ma ona zbyt wielu własnych surowców energetycznych $\mathrm{w}$ porównaniu $\mathrm{z}$ głównymi konkurentami w skali światowej. Prowadzona przez UE polityka energetyczna powinna wspierać wdrażanie nowych technologii w sektorze energii oraz zwiększać efektywność energetyczną, polityka klimatyczna zaś musi być oparta na porozumieniu globalnym, a dopiero w dalszej kolejności na porozumieniu unijnym.

\section{Literatura}

[1] Are we entering a golden age of gas? Special Report, World Energy Outlook 2011, International Energy Agency, France 2011. 
[2] Bezpieczeństwo energetyczne Polski 2010. Raport otwarcia, Instytut Kościuszki, Kraków 2010.

[3] Czaputowicz J., Teorie stosunków międzynarodowych. Krytyka i systematyzacja, Wydawnictwo Naukowe PWN, Warszawa 2008.

[4] Depail J.-C., Gas proces in Europe will drop, [w:] Future of Gas - A strategic view into the future, report summarizing 10th international conference of Gas Infrastructure Europe, Kraków 24-25 May 2012.

[5] Kaliski M., Szurlej A., Grudziński Z., Węgiel i gaz ziemny w produkcji energii elektrycznej Polski i UE, „Polityka energetyczna” 15/4 (2012).

[6] Kaźmierczak T., Bezpieczeństwo energetyczne - implikacje uzależnienia Polski od importu gazu ziemnego (zarys problemu), Promotor, Warszawa 2008.

[7] Łoś - Nowak T., Stosunki międzynarodowe. Teorie - systemy - uczestnicy, Wydawnictwo Uniwersytetu Wrocławskiego, Wrocław 2000.

[8] Morgenthau H., Politics among Nations. The Struggle for Power and Peace, New York 1967.

[9] Rozporzadzeniu Parlamentu Europejskiego i Rady (UE) $n r$ 994/2010 z dnia 20 października 2010 r. w sprawie środków zapewniajacych bezpieczeństwo dostaw gazu ziemnego i uchylenia dyrektywy Rady 2004/67/WE, Dz. U. UE L 295/1.

[10]Rozporzadzenie Parlamentu Europejskiego i Rady (UE) Nr 347/2013 z dnia 17 kwietnia 2013 r. $w$ sprawie wytycznych dotyczacych transeuropejskiej infrastruktury energetycznej, uchylajace decyzje $n r$ 1364/2006/WE oraz zmieniajace rozporzadzenia (WE) $n r$ 713/2009, (WE) $n r$ 714/2009 $i$ (WE) $n r$ 715/2009, Dz. U. UE L 115/39.

[11]Rozporządzenie Rady Ministrów z dnia 24 października 2000 r. w sprawie minimalnego poziomu dywersyfikacji dostaw gazu z zagranicy, Dz. U. Nr 95, Poz. 1042.

[12]Zawisza A., Gaz dla Polski. Zarys historii sektora gazu ziemnego w ostatnich dwóch dekadach w Polsce, Instytut Sobieskiego, Warszawa 2011.

[13]www.cire.pl

[14]www.gaz-system.pl

[15]www.gazetaprawna.pl

[16]www.gazeta.pl

[17]www.wnp.pl

\section{INFRASTRUCTURE POSSIBILITY OF DIVERSIFICATION OF NATURAL GAS SUPPLY TO POLAND - PERSPECTIVE 2020}

Diversification of sources of the supply of natural gas to Poland is one of the crucial factor which supports country's energy security. This fuel is used in Poland mainly by the chemical industry and petrochemical companies and its role will grow in the whole world over in the coming time because of the more and more stricter EU' climate policy. The level of domestic natural gas production accounted for some $30 \%$ of the country's demand and the remaining 70\% imported from the east direction from Russian's company Gazprom. By the structure of the existing long-term contracts Poland is depended on natural gas supply from Gazprom. The best solution to change the situation is to develop the energy infrastructure especially terminal LNG in Świnoujście as well as interconnections of natural gas (interconnectors) with neighbouring countries. The implementation of EU's rules in combination with the construction of the common energy market and with the development 
of gas infrastructure makes, that Poland will increase the opportunities to diversify sources of supply of this fuel. Poland will become an important part of integrated energy market and change the directions of natural gas supply if the most important energy infrastructure projects planned by the company Gaz-System is completed. It is supposed that with the opening of competition in the Polish energy market will be increased the activity of foreign energy companies that will try to compete with Polish companies for consumers. Especially the activity should be demonstrated by the Russian and German companies. The creation of common energy market EU could lead to the situation that natural gas will become widely available energy resource and its price will be more and more competitive.

Keywords: diversification, natural gas, energy infrastructure, LNG terminal, energy security

DOI:10.7862/rz.2013.hss.51

Tekst złożono w redakcji: wrzesień 2013.

Przyjęto do druku: marzec 2014. 